\section{DDT reintroduction for malaria control: the cost-benefit debate for public health}

\author{
Reintrodução do DDT para combate à malária: \\ uma discussão de custo-benefício \\ para a saúde pública
}

\author{
I Instituto de Estudos em \\ Saúde Coletiva, Universidade \\ Federal do Rio de Janeiro, Rio \\ de Janeiro, Brasil. \\ 2 Núcleo de Estudos da Saúde \\ do Adolescente, Universidade \\ do Estado do Rio de Janeiro, \\ Rio de Janeiro, Brasil. \\ 3 Escola Nacional de Saúde \\ Pública Sergio Arouca, \\ Fundação Oswaldo Cruz, Rio \\ de Janeiro, Brasil. \\ Correspondence \\ R. M. Guimarães \\ Instituto de Estudos em \\ Saúde Coletiva, Universidade \\ Federal do Rio de Janeiro. \\ Av. Brigadeiro Trompowski \\ $s / n$, Praça da Prefeitura \\ da Cidade Universitária, \\ Rio de Janeiro, $R J$ \\ 21949-900, Brasil. \\ raphaelscoletiva@gmail.com
}

\section{Abstract}

DDT is a persistent insecticide that was widely used in the world from the 1940s until the 70s, when it was banned in the United States and other countries. Most of its toxic effects are not observed in the acute forms, but particularly after chronic exposure. These long-term issues include reproductive effects, varying according to the time of life in which the individuals were exposed. The aims of the current study were to review the principal toxicological effects of DDT on reproduction, stratifying by physiological periods of exposure, and based on the magnitude of these effects, to discuss the cost-benefit relationship of reintroducing DDT with the specifically defined vector control criteria.

DDT; Pesticide Exposure; Malaria
Raphael Mendonça Guimarães 1

Carmen Ildes Rodrigues Fróes Asmus 1,2

Armando Meyer 1,3

\section{Introduction}

The impact of pesticides on human health has received worldwide attention from the scientific community, especially in developing countries, where the use of these compounds has increased rapidly. Their evaluation requires knowledge and a clear view of the relative importance and magnitude of each of the contamination routes 1 .

Pesticides appeared in Brazil in the 1960s and 1970s as a scientific solution for pest control in crops and livestock ${ }^{2}$. Earlier, in the 1940s, some substances with insectidal properties had already been used to control certain endemic diseases like malaria and schistosomiasis 3 .

A first class of pesticides that was widely used in public health consisted of the organochlorines, among which the most widely known example is dichlorodiphenyltrichloroethane, or DDT.

A previous publication 4 described the discovery of the insecticidal power of DDT, the first synthetic organic insecticide, launching the era of the organochlorine pesticides. Beginning with DDT, a growing number of pesticides emerged. During World War II, and DDT was widely used by the U.S. Army in campaigns in various regions of the world, after which its use became widespread 5 . Despite the benefits, the indiscriminate use of this class of substances led to serious ecological problems. It is now estimated that nearly all living beings, both plant and animal, are contaminated by organochlorine insecticides 4 . 
Concern over the use of DDT began in the 1960s, when the famous book Silent Spring by Rachel Carlson ${ }^{6}$ described a series of harmful effects on the environment and wildlife resulting from pesticide use. The author specifically emphasized the effect of DDT in weakening the eggshells of the American eagle (Haliaetus leucocephalus), contributing to a sharp decline in this species. In addition, due to its high persistence in the environment and numerous reports of resistant insect species, DDT was gradually replaced with other substances in many developed countries.

In Brazil, DDT was banned from agricultural use in 1985. In 1997, the Fundação Nacional de Saúde [FUNASA; National Health Foundation] also banned its use for vector control. Finally, since 1998 there has been a total ban on DDT for any use in Brazil 3. However, in some countries with endemic malaria areas, DDT is still widely used. Since economic interests often clash with the need for environmental protection, DDT is still produced and exported in large amounts by countries that have already banned its use in their own territories 7. A well-known case of the use of DDT that generated known environmental impacts was Cidade dos Meninos in Rio de Janeiro, where an old Ministry of Health insecticide factory that had been closed down in the 1950s released large amount of insecticides into the air, particularly hexachlorocyclohexane $(\mathrm{HCH})$ and DDT 3 .

DDT exerts its action on the physical makeup and health of humans, in addition to contaminating the environment and animal populations. Thus, understanding DDT's mechanisms of action is crucial for evaluating the impact of such contamination on human health.

We currently have a considerable body of knowledge on the multiple toxic effects of DDT 8. Particularly in the last 15 years, great attention has focused on this insecticide's possible estrogenic and anti-androgenic effects and how such interference with the endocrine system's homeostasis represents a mechanism of action that explains part of the compound's toxic effects 7 . Furthermore, DDT byproducts have been linked to infertility, miscarriage, and breast cancer, and such effects are modulated according to the stage of life in which the individual was exposed.

Beyond this accumulated knowledge, there is an impasse in the scientific community on the reintroduction of DDT in countries where endemic diseases whose vectors can be eliminated by DDT are demanding its renewed use. They base their argument on a cost-benefit discourse, given the high mortality rates from vector-borne diseases like malaria and yellow fever. A recent article 8 reviewed the main characteristics of this organochlorine and some aspects of its use in leishmaniasis and malaria vector control. Considering the compound's description and one of the possible groups of outcomes in humans, namely its endocrine-modulating and reproductive effects, the current article has the following objective: to review the main toxic effects of DDT related to the reproductive system's biochemical and physiological mechanisms, according to the specific period of life in which the individual is exposed; based on the magnitude of these effects, to discuss the cost-benefit relationship involved in the possible reintroduction of DDT with specifically defined vector control criteria. The first part of the article reviews some key aspects of DDT toxicology, after which we list some studies that have examined the relationship between DDT exposure and selected outcomes; finally, the discussion develops and presents arguments for and against the reintroduction of DDT as a vector control pesticide.

\section{Chemical properties of DDT}

DDT (dichlorodiphenyltrichloroethane) is a syntheticinsecticidebelonging to the organochlorine chemical class. DDT also has several metabolites, emphasizing DDE and DDD. Both DDE and DDD are byproducts of DDT. All the isomers are solid, white, odorless, and tasteless substances, with the empirical formula $\mathrm{C}_{14} \mathrm{H}_{9} \mathrm{C}_{15} 9,10$.

DDT's persistence is due to its great chemical and physical stability and its slow and partial biodegradation 5 . Since DDT possesses optical isomerism, the commercial product is a mixture of two isomers (op'DDT, some $23 \%$, and pp'DDT, some $77 \%$ ) obtained as a compound with a high degree of purity through the reaction of a chlorobenzol molecule with a chloral hydrate molecule in the presence of sulfuric acid 10 .

\section{DDT toxicology}

Although DDT is a potent contact insecticide with prolonged residual action in the sites where it is applied, and although the underlying mechanism of its neurotoxic effects is essentially the same in insects and vertebrates, this organochlorine's toxicological record can be considered relatively clean 10,11. Despite its intense and careless use for decades in many countries, known cases of acute DDT intoxication in humans are rare, and there are even fewer reports of deaths caused by this insecticide. This selective biocidal action is explained by the fact that DDT is readily absorbed by the insect's chitinous exoskeleton, while the 
corneal layer of keratinous cells in mammalian skin acts as an efficient barrier against the insecticide's penetration 10 .

We can assume that nearly all individuals born since the mid-1940s have been exposed to DDT for a major portion of their lives and have accumulated it in their fatty tissue 11. Maintaining a constant rate of entry into the body, DDT concentration reaches a stationary level in the adipose tissue and remains relatively constant.

DDT can be absorbed by inhalation or ingestion, depending on the vehicle used. In mammals, including humans, after being absorbed by the oral or respiratory route, DDT is broken down by two routes: the principal form of metabolism is its transformation into the unsaturated compound DDE, through the loss of hydrogen and chlorine.

In order to be excreted, DDT is slowly dechlorinated and oxidized by cytochrome p450dependent monooxygenases to intermediate metabolites, among which p,p'-DDE, one of the most persistent in mammals 10,11. DDE is virtually non-biodegradable, not undergoing subsequent transformation, and since it is highly fat-soluble, it tends to be deposited in the body, especially in adipose tissue.

The second metabolic route is transformation into the saturated compound DDD, through the substitution of a hydrogen atom with a chlorine atom and continuing metabolism through a series of intermediate compounds until DDA [bis(p-chlorophenyl)acetic acid], which is water-soluble and excreted in the bile, feces, and urine 5,8. Another metabolic route, unlike that with p,p'-DDE as the intermediate route, results in DDA excreted in the urine. DDA, originating from technical DDT or p,p'-DDT, but not from p,p'-DDE, is found in considerable amounts in the urine in cases of acute intoxication and intense and recent occupational exposure 10.

For a long time, DDT has been known to deposit in human adipose tissue 12. Since DDT crosses the placental barrier and is eliminated in human breast milk, even newborns and nursing infants have detectable amounts 5 .

The underlying mechanism of both the insecticidal action and acute toxic effects of DDT involves the alteration of neuronal electrical excitability, respectively in insects and vertebrates 13,14. In axons exposed to DDT, the descending phase of the action potential is prolonged (negative post-potential), thus returning more slowing to resting (baseline) potential 5,13. This effect results in delayed repolarization of the neuronal membrane.

Thus, the membrane of a nerve cell exposed to DDT remains partially depolarized after the action potential, making it highly susceptible to stimulation 14 .

These alterations caused by DDT are manifested as neuronal hyperexcitability with repetitive firing of action potentials after sensory stimulation (hyper-responsiveness to stimuli) 5,10,13. This explains why acutely intoxicated individuals display the characteristic symptoms of DDT neurotoxic action, namely persistent tremor and/or seizures $10,13,14,15,16,17$.

There are four possible mechanisms for explaining how DDT prolongs the negative postpotential and increases neuronal excitability in the central and peripheral nervous systems: altered permeability of the axonal membrane to potassium; slower inactivation of sodium channels; inhibition of neuronal adenosine triphosphatase (ATPase), particularly $\mathrm{Na}+/ \mathrm{K}+-\mathrm{de}$ pendent ATPase and also $\mathrm{Ca}++/ \mathrm{Mg}++-A T P a s e ;$ finally, inhibition of the capacity of calmodulin to bind to and transport calcium ions, which are essential for the intra-neuronal release of neurotransmitters 11,13,17.

\section{Health effects}

It was formerly believed that DDT and its metabolites did not possess endocrine effects, but in the 1970s and 80s several studies 18,19 suggested that DDT mimics estrogens, i.e., possessing similar pharmacological properties to $\beta$-estradiol. This gave rise to extensive investigation on the possible hormonal effects of human exposure to DDT and it byproducts.

These compounds can indeed act as estrogen agonists, since they can induce estrogenic effects when they bind to specific receptors. The possibility that they exert a complex effect by interacting with different steroidal hormone receptors at different levels, with as-yet unknown biochemical and physiological consequences, requires further investigation 20 .

Although many of the most important organizational events giving rise to an adult with reproductive capacity take place in the uterus, other equally important events occur over the course of extra-uterine life. Such time periods (during which the reproductive system's development is more susceptible to transformations, including those produced by xenobiotics) have been well characterized in the scientific literature 20,21,22.

Preconceptional exposures are defined here as those affecting spermatogenesis in men, while in women this phase corresponds to the point at which the gametes emerge from the primordial follicular state and proceed to the primary and secondary follicles and become fertile 21 . 
The prenatal period is divided into two phases: the first phase ranges from fertilization until genital development. However, the critical time for deleterious effects in the reproductive system is during the second phase, from genital development until birth 22 .

Meanwhile the post-natal period basically involves the individual's fertility potential, from regulation of ovarian function to the quality of sperm production 22. This phase also includes puberty, particularly involving finalization of the sexual maturation processes.

\section{Preconception}

A study of young males in an area sprayed with DDT in Mexico found an inverse association between blood DDT concentration and sperm count and testosterone concentration 23 . Hauser et al. 24,25 found a weak inverse association with sperm motility, but not with concentration, morphology, or altered DNA, when observing a population of 212 adults in their 30s who were partners of women considered sub-fertile in the United States. Waissmann 26 reported an association between DDT and some other solvents and decreased fertility and viable sperm concentration in semen.

DDT and its metabolites commonly show an estrogenic effect; particularly, the metabolites o,p'-DDT; p,p'-DDT; p,p'-DDE; o,p'-DDE, and $o, p^{\prime}-D D T$ are estrogen receptor ligands in estrogen-responsive cells 27,28 . Some epidemiological studies have shown the estrogenic effects arising from this interaction. For example, Akkina et al. 29, in a sample of 219 Hispanic women living in the United States who suffered DDT intoxication, found a high DDE concentration associated with early menopause. Cohn et al. 30 , in a sample of 289 women born in the early 1960s in the United States, showed an association between DDT exposure and decreased odds of pregnancy.

\section{Prenatal period}

DDT easily crosses the placenta and is found in the umbilical cord blood of neonates born to mothers exposed to this insecticide 7 . Still, there is no experimental or epidemiological evidence that DDT is teratogenic in mammals, i.e., there is no consistent indication that this insecticide causes malformations in offspring exposed during prenatal development 5,10 .

Hosie et al. 31 analyzed the blood organochlorine levels in adipose tissue samples from 48 boys, 18 of whom with cryptorchidism (undescended testes). The authors did not find any differences between boys with and without cryptorchidism in terms of DDT and its metabolites, polychlorinated biphenyls (PCBs), toxaphenes, $\mathrm{HCH}$, and other related compounds. However, increased concentrations of heptachlor-epoxide (HEP) and hexachlorobenzene (HCB) were observed in boys with cryptorchidism 31 .

An epidemiological study on the east coast of Sweden in a retrospective cohort of fishermen's wives observed that high consumption of fish from the Baltic Sea (principal source of this population's contamination by persistent organochlorine compounds, including PCBs, PCDD/Fs, and DDT) was not associated with a higher frequency of miscarriage and/or stillbirth 32 .

As for the chronic effects of organochlorines and DDT, specifically related to obstetric events, the results are still conflicting. Fenster et al. 33 analyzed a cohort of 385 low-income Latino women living in a rural community in California. The authors observed an inverse association between the plasma concentration of HCB-impregnated lipids and fetal growth and delayed gestational age. However, they found no statistically significant association between prematurity and any type of organochlorine. According to Rogan \& Chen 34 , various previous descriptive and analytic studies identified a strong association between breast cancer and high plasma DDT levels. However, this association has now been challenged, and they report the need to adjust for possible confounders, like degree of exposure, type of DDT metabolites, estrogenic variants, age at menopause, diet, breastfeeding history, different population types, ethnicity, tumor characteristics, and polymorphisms.

In relation to obstetric effects, Korrick et al. 35 found an increase in serum DDE associated with an increase in the risk of miscarriage in a group of 15 cases and 15 controls in China. Furthermore, Longnecker et al. 36 evaluated a group of 1,717 pregnant women in the United States and observed an increase in serum DDE associated with a history of miscarriage and stillbirth in previous pregnancies.

Longnecker et al. 28 analyzing a cohort of 2,613 pregnant women in the United States, found a strong association between serum DDE levels and prematurity. The same conclusion appeared in a case-control study with 100 cases of prematurity in Mexico by Torres-Arreola et al. 37 .

As for birth defects, a case-control study by Longnecker et al. 38 including 219 boys with cryptorchidim, 199 with hypospadia (closure disorder of the urethral canal), and 167 with polythelia, and 552 controls in the United States showed a slightly increased risk in the association between DDE and such malformations, but the results were inconclusive. Bhatia et al. 39 , in 
a similar study with 75 cases of cryptorchidism, 66 cases of hypospadia, and 283 controls in the United States, found a similar slight, non-significant increase for both malformations.

\section{Post-natal}

Beard et al. 40 examined the relationship between plasma DDE and bone mineral density (BMD) in 68 sedentary women who reported adequate dietary calcium intake and found results suggesting that DDT exposure might be associated with reduced $\mathrm{BMD}$.

DDT can also delay puberty. The estrogenlike activity of DDT and its isomers is weak as compared to estradiol. However, its bioaccumulation property and long half-life show that human exposure can have estrogen-like effects in some circumstances 5,41,42,43.

Turusov et al. 44 report the estrogen-like potential of DDT, assessed in vivo and in vitro. In the former, tests in oophorectomized rats or those with low-weight uteruses showed an important response to the metabolite o,p'-DDT, inhibiting estradiol binding to uterine receptors. In the latter, some DDT and DDE metabolites proved capable of inducing MCF-7 cell proliferation in breast tumors, which are estrogendependent 44 .

DDT belongs to group IIb in the classification of the International Agency for Research on Cancer (IARC), i.e., possibly carcinogenic in humans 45 . The IARC data allow concluding that there is an association between DDT use and cancer in animals. However, the Agency for Toxic Substances and Disease Registry (ATSDR) 10 considers the studies in human contradictory. There was an increased risk of post-DDT-exposure pancreatic cancer, as well as excess incidence of liver cancer and multiple myeloma following occupational exposure to DDT; however, the association was not confirmed, and the exposure conditions were not compared. The association in humans is thus inconclusive 9 .

Some researchers have made the connection between organochlorine exposure and increased cancer in humans. A hypothesis based on biochemical and epidemiological aspects suggests that organochlorine pesticides may trigger breast cancer due to the adverse effect on estrogen metabolism 45 .

DDT and its metabolites have been referred to as endocrine disrupters, due to evidence suggesting that they can alter the normal function of the endocrine system and contribute to breast cancer. Dich et al. 46 reviewed the relationship between pesticides and various types of cancers. They found a relationship with soft tissue sarco- ma, non-Hodgkin lymphoma, and leukemia, and less consistently with lung and breast cancer.

There is also evidence that organochlorine pesticides act as active promoters of carcinogenesis, i.e., not inducing the genetic event that participates in the initiation phase of cancer, but potentiating or "promoting" the clonal expansion of the initiated cells 46,47 . Breast cancer mortality is inversely correlated with DDE levels in adipose tissues in whites and blacks. None of the other cancer types showed a positive correlation with DDE concentration in adipocytes, except in liver cancers, with a positive correlation in whites and a negative correlation in blacks (Cocco et al., 2000, apud Snedeker 48).

Romieu et al. 49 analyzed the relationship between breastfeeding history, plasma DDT and DDE levels, and breast cancer risk in a study of women living in Mexico City from 1990 to 1995. Serum DDT level was not associated with cancer risk, but the presence of high DDE levels, principally among post-menopausal women, can increase breast cancer risk. Bohannon et al. 50 in a cohort of 1,407 women with breast cancer in a case-control study in the United States, observed an association between this outcome and serum DDE level.

\section{Reintroduction of DDT: costs and benefits}

There is an intense debate in the United Nations Environment Program (UNEP) concerning the ban on DDT and 11 other persistent organic pollutants 51 . However, there are regions in the world where DDT use is the only malaria vector control strategy, as in some countries in Africa, Asia, and Latin America. One position thus defends the restricted use of this compound for public health purposes, as long as the cost-benefit relationship between risk and positive effects is favorable, and where there is no other vector control alternative, meanwhile without failing to signal the need to invest in research resulting in malaria vaccines or the development of other types of insecticide 33,51 .

In principle, DDT was banned due to its adverse effects on the environment, like the high persistence in different environmental compartments and bioaccumulation and biomagnification in living organisms, including human beings 43 .

In September 2006, the World Health Organization (WHO) recommended the use of household spraying with DDT and other insecticides for malaria control 52,53,54,55,56. At that time, the WHO cited many reasons for using DDT for this 
purpose, including that DDT has a longer action time, and thus fewer household sprayings are needed, so that it is capable of repelling mosquitoes from inside dwellings and killing those present on sprayed surfaces 53,56 . Since then, some African countries began to reintroduce DDT in their endemic disease control activities 54,55.

Recent publications have resumed this discussion on the benefit of reintroducing DDT. Rehwagen 57 notes that the last WHO recommendation tends towards the use of DDT not only in epidemic areas, but also in those with high and constant malaria transmission rates, which includes all of Africa. Mandavilli 58,59 reiterates this observation.

According to Rogan \& Chen 34 , when the global ban on DDT was proposed in 2001, numerous countries in Sub-Saharan Africa claimed that DDT was still necessary as a cheap and effective form of vector control, especially contributing to the reduction of child mortality. In this study, the author also describes research showing that DDT exposure in the amounts needed for malaria control could cause pre-term birth, thus overweighing the benefit of reducing the infant mortality from malaria. They conclude the study by recommending that DDT might be useful for malaria control, but that the evidence of adverse effects on human health requires appropriate research to determine whether there is in fact a positive cost-benefit relationship with its use.

Some recent studies have shown diverging opinions. Maharaj et al. 60 attempted to determine whether reintroducing DDT in vector control would have some effect on malaria transmission in the province. The study was designed after the local malaria epidemic in 2000 was attributed to vector resistance to pyrethroids. Their conclusion was that reintroducing DDT had a positive impact on malaria control, contributing to a reduction of up to $91 \%$ in cases, together with other measures like chemotherapy. Still, they highlight that the success was due to the adoption of multiple strategies, and that routine practice includes the exclusive and continuing use of DDT in endemic malarias areas in the province. They also report that this practice is currently threatened by the emergence of DDT resistance.

A recent article by Etang et al. ${ }^{61}$ showed deleterious mutations in the Leu-Phe and Leu-Ser amino acid sequences in Anopheles gambiae mosquitoes associated with pyrethroid or DDT resistance in Cameroon. Meanwhile, Cui et al. 62 state that in China, large amounts of four classes of insecticides (organochlorines, organophosphates, carbamates, and pyrethroids) are sprayed yearly in fields and plantations, thereby leading directly or indirectly to a rigorous natural selec- tion of the vector population. Cui et al. 62 also describe seven classes of the most frequent mosquitoes in China, like the Aedes, Anopheles, and Culex genera, all of which are disease vectors, and all of which except the carbamates have generally presented resistance to pesticides.

Some public health programs have focused on studying the cost-effectiveness of this practice with DDT, for example in Cameroon 63, Mozambique 64, Kenya 65, South Africa 66, India 67, Vietnam 68, Eritrea 69, and Ghana 70. In general, the continuous use of DDT for vector control, but not for agriculture - the condition approved by the Stockholm Convention on Persistent Organic Pollutants - has proven to be a good alternative for malaria control.

There are also other highly successful experiences in countries that have used environmental modification programs to eradicate mosquito larvae, as in the case of Malaysia 71 and Zambia 72 , using water level variation in reservoirs, intermittent irrigation in agriculture, removal of part of the emerging vegetation, and even introduction of larvicidal biological agents in the environment, like bacteria 73 , fungi 74 , and some algae 75 . These are believed to be alternatives to DDT use. However, little is said about their environmental impact, especially for those that alter the ecosystem. It is still not known whether these measures may be as harmful or even worse than DDT itself.

The range of studies shows the great variability in DDT resistance, according to the target area. Such evidence requires more in-depth research to reach a conclusion on this relationship. It is also necessary to obtain genetic monitoring data on mosquito strains to verify the possibility of vector migration from areas where they are resistant to areas where they are susceptible.

DDT use thus remains as an issue for decision-makers in endemic malaria areas due to its historical success in malaria control. To make an evidence-based decision, health system managers will face the difficult task of estimating the risk and benefits. The association between DDT and certain types of cancer (e.g., of the breasts, endometrium, ovaries, prostate, testes, and thyroid) and other endocrine effects is still a controversial issue 76 . Cocco 77 provides a review of experimental and epidemiological studies suggesting or refuting the associations, but which were modeled and designed differently.

DDT is far from problem-free. Some African countries that export farm produce remain concerned about a possible boycott of their products by European Union countries, which now seek to set tolerance limits well below those of other developed countries like the United States and 
Japan 78 . The global community needs to be sure that DDT is only used to fight malaria mosquitoes, and not the African economy. The commitment by non-African countries to reintroducing DDT is thus indispensable. Thus, eradicating the mosquito to prevent malaria mortality implies that the African countries should have relative economic stability with this new social standard.

The debate over vector control vis-à-vis malaria resurgence is still vital, but it should include all the relevant evidence for countries with social weaknesses. For example, as an endocrine disruptor, DDT is capable of decreasing ductal sensitivity to prolactin, decreasing the amount of breast milk produced, and thus shortening breastfeeding time $5,10,14$. This fact is non-negligible, considering that breast milk is often the only meal for African infants, even those over six months of age 79,80 .

\section{Conclusion}

Malaria is a major public health problem, and effective treatment and prevention efforts are necessary. This article proposed to help elucidate the issue by highlighting some endocrine and reproductive outcomes of chronic DDT exposure.
The Global Strategy for Malaria Control is the focus of intense discussion in the international arena $57,59,78$. We are still far from reaching a consensus on DDT use for controlling endemic diseases. There is considerable evidence on DDT's adverse effects on the environment and human health 77 . Still, malaria is a serious public health problem in developing countries like those of Sub-Saharan Africa, leading to extensive mortality 81 . According to some authors, the malaria cases and deaths that could be averted by DDT far outweigh the health problems arising from its use $81,82,83$. Meanwhile, others have shown a clear concern over the future use of DDT (even if rationally applied) for vector control 34,77.

There is no ideal solution to vector control problems. Even intradomiciliary DDT spraying has its limitations 82 . However, in many places, especially in the Sub-Saharan countries, it is the best or even the only form of control ${ }^{81}$. This is not a closed discussion, quite to the contrary. We must assess the short-term benefits that DDT will bring for countries with adverse endemic malaria statistics, without losing sight of the probable long-term harms from exposure to this insecticide. Based on this assessment, we should rely on common sense to reach the best decision.

\section{Resumo}

O DDT é um inseticida persistente que foi amplamente utilizado no mundo a partir da década de 40 até a de 70, quando foi banido nos Estados Unidose outros países. A maioria dos efeitos de sua toxicidade não é observável em formas agudas, mas especialmente após exposições crônicas. Dentre estes aspectos em longo prazo estão os efeitos reprodutivos, que variam de acordo com o a época da vida em que as pessoas foram expostas. Os objetivos deste estudo são: revisar os principais efeitos toxicológicos do DDT na reprodução, estratificando de acordo com os períodos fisiológicos de exposição; e a partir da magnitude destes efeitos discutir o custo-benefício da volta da utilização do DDT com critérios definidos de eliminação de vetores da malária.

DDT; Exposição a Praguicidas; Malária

\section{Contributors}

All the authors participated in the selection of material, drafting of the paper, and discussion and final review of the article. 


\section{References}

1. Agência Nacional de Vigilância Sanitária. Programa de análise de resíduos de agrotóxico em alimentos. Relatório anual 04/06/2001-30/06/2002. Brasília: Agência Nacional de Vigilância Sanitária; 2002.

2. Peres F, Oliveira-Silva JJ, Della-Rosa HV, Lucca SR. Desafios ao estudo da contaminação humana e ambiental por agrotóxicos. Ciênc Saúde Coletiva 2005; 10:27-37.

3. Braga AMCB. Contaminação ambiental por hexaclorociclohexano em escolares na Cidade dos $\mathrm{Me}$ ninos, Duque de Caxias, Rio de Janeiro [Masters Thesis]. Rio de Janeiro: Escola Nacional de Saúde Pública, Fundação Oswaldo Cruz; 1996.

4. Flores AV, Ribeiro JN, Neves AA, Queiroz ELR. Organoclorados: um problema de saúde pública. Ambiente \& Sociedade 2004; 7:111-24.

5. Klaassen CD. Casarett and Doull's toxicology: the basic science of poisons. $6^{\text {th }}$ Ed. Philadelphia: McGraw-Hill; 2001.

6. Carlson R. Silent spring. New York: Fawlett Cresa Books; 1962.

7. Meyer A, Sarcinelli PN, Abreu-Vilaça Y, Moreira JC. Os agrotóxicos e sua ação como desreguladores endócrinos. In: Peres F, organizador. É veneno ou remédio? Agrotóxicos, saúde e ambiente. Rio de Janeiro: Editora Fiocruz; 2003. p. 101-18.

8. D'Amato C, Torres JPM, Malm O. DDT (dicloro difenil tricloroetano): toxicidade e contaminação ambiental - uma revisão. Quími Nova 2002; 25:995-1002.

9. World Health Organization. Environmental health criteria: DDT and its derivatives - environmental aspects. Geneva: World Health Organization; 1989.

10. Agency for Toxic Substances and Disease Registry. Toxicological profile for DDT/DDD/DDE (update). Atlanta: Agency for Toxic Substances and Disease Registry; 2002.

11. La Dou J. Current occupational \& environmental medicine. 3rd Ed. Philadelphia: McGraw-Hill; 2004.

12. Read ST, McKinley WP. DDT and DDE content of human fat: a survey. Arch Environ Health 1961; 3:209-11.

13. Kasper DL, Braunwald E, Fauci A, Hauser S, Longo D, Jameson JL. Harrison's principles of internal medicine. 16 th Ed. New York: McGraw-Hill; 2005.

14. Rosenstock L, Cullen M, Brodkin C, Redlich C. Textbook of clinical occupational and environmental medicine. Philadelphia: W.B. Saunders; 1994.

15. Felig P, Baxter JD, Frohman LA. Endocrinology and metabolism. 3rd Ed. New York: McGraw-Hill; 1995.

16. Mendes R. Patologia do trabalho. 2a Ed. Rio de Janeiro: Editora Atheneu; 2005.

17. Nelson DL, Cox MM. Lehninger's principles of biochemistry. 4th Ed. New York: McGraw-Hill; 2004.

18. Bitman J, Cecil HC. Estrogenic activity of DDT analogs and polychlorinated biphenyls. J Agric Food Chem 1970; 18:1108-12.

19. Bryan TE, Gildersleeve RP, Wiard RP. Exposure of Japanese quail embryos to o,p'-DDT has longterm effects on reproductive behaviors, hematology, and feather morphology. Teratology 1989; 39: 525-35.
20. Lemasters GK, Perreault SD, Hales BF, Hatch M, Hirshfield AN, Hughes CL, et al. Workshop to identify critical windows of exposure for children's health: reproductive health in children and adolescents work group summary. Environ Health Perspect 2000; 108 Suppl 3:505-9.

21. Pryor JL, Hughes C, Foster W, Hales BF, Robaire B. Critical windows of exposure for children's health: the reproductive system in animals and humans. Environ Health Perspect 2000; 108 Suppl 3:491503.

22. Selevan SG, Kimmel CA, Mendola P. Identifying critical windows of exposure for children's health. Environ Health Perspect 2000; 108 Suppl 3:451-5.

23. Ayotte P, Giroux S, Dewailly E, Hernández Avila M, Farias P, Danis R, et al. DDT spraying for malaria control and reproductive function in Mexican men. Epidemiology 2001; 12:366-7.

24. Hauser R, Chen Z, Pothier L, Ryan L, Altshul L. The relationship between human semen parameters and environmental exposure to polychlorinated biphenyls and p,p-DDE. Environ Health Perspect 2003; 111:1505-11.

25. Hauser R, Chen Z, Pothier L, Ryan L, Altshul L. Lack of an association between environmental exposure to polychlorinated biphenyls and p,p-DDE and DNA damage in human sperm measured using the neutral comet assay. Hum Reprod 2003; 18:2525-33.

26. Waissmann W. Endocrinopatologia associada ao trabalho. In: Mendes R, organizador. Patologia do trabalho. São Paulo: Editora Atheneu; 2003. p. 1093-138.

27. Mantovani A. Problems in testing and risk assessment of endocrine disrupting chemicals with regard to developmental toxicology. Chemosphere 1999; 39:1293-300

28. Longnecker MP, Klebanoff MA, Zhou H, Brock JW. Association between maternal serum concentration of the DDT metabolite DDE and preterm and small-for-gestational-age babies at birth. Lancet 2001; 358:110-4.

29. Akkina J, Reif J, Keefe T, Bachand A. Age at natural menopause and exposure to organochlorine pesticides in Hispanic women. J Toxicol Environ Health A 2004; 67:1407-22.

30. Cohn BA, Cirillo PM, Wolff MS, Schwingl PJ, Cohen RD, Sholtz RI, et al. DDT and DDE exposure in mothers and time to pregnancy in daughters. Lancet 2003; 361:2205-6.

31. Hosie S, Loff S, Witt K, Niessen K, Waag KL. Is there a correlation between organochlorine compounds and undescended testes? Eur J Pediatr Surg 2000; 10:304-9.

32. Axmon A, Rylander L, Strömberg U, Hagmar L. Miscarriages and stillbirths in women with a high intake of fish contaminated with persistent organochlorine compounds. Int Arch Occup Environ Health 2000; 73:204-8. 
33. Fenster L, Eskenazi B, Anderson M, Bradman A, Harley K, Hernandez H, et al. Association of in utero organochlorine pesticide exposure and fetal growth and length of gestation in an agricultural population. Environ Health Perspect 2006; 114:597-602.

34. Rogan WJ, Chen A. Health risks and benefits of bis(4-chlorophenyl)-1,1,1-trichloroethane (DDT). Lancet 2005; 366:763-73.

35. Korrick SA, Chen C, Damokosh AI, Ni J, Liu X, Cho SI, et al. Association of DDT with spontaneous abortion: a case-control study. Ann Epidemiol 2001; 11:491-6.

36. Longnecker MP, Klebanoff MA, Zhou H, Brock JW. Maternal serum level of the DDT metabolite DDE in relation to fetal loss in previous pregnancies. Environ Res 2005; 97:127-33.

37. Torres-Arreola L, Berkowitz G, Torres-Sánchez L, López-Cervantes M, Cebrián ME, Uribe M, et al. Preterm birth in relation to maternal organochlorine serum levels. Ann Epidemiol 2003; 13:158-62.

38. Longnecker MP, Klebanoff MA, Zhou H, Brock JW. Maternal serum level of 1,1-dichloro-2,2-bis(p chlorophenyl)ethylene and risk of cryptorchidism, hypospadias, and polythelia among male offspring. Am J Epidemiol 2002; 155:313-22.

39. Bhatia R, Shiau R, Petreas M, Weintraub JM, Farhang L, Eskenazi B. Organochlorine pesticides and male genital anomalies in the child health and development studies. Environ Health Perspect 2005; 113:220-4

40. Beard J, Marshall S, Jong K, Newton R, Triplett-McBride T, Humphries B, et al. 1,1,1-trichloro-2,2-bis (p-chlorophenyl)-ethane (DDT) and reduced bone mineral density. Arch Environ Health 2000; 55: 177-85.

41. Jequier AM. Male infertility: a guide for the clinician. Oxford: Blackwell Science; 2002.

42. Meltzer M, editor. The handbook of environmental chemistry. Berlin: Springer-Verlag; 2002.

43. Meyer A, Sarcinelli PN, Moreira JC. Estarão alguns grupos populacionais brasileiros sujeitos à ação de disruptores endócrinos? Cad Saúde Pública 1999; 15:845-50.

44. Turusov V, Rakitsky V, Tomatis L. Dichlorodiphenyltrichloroethane (DDT): ubiquity, persistence, and risks. Environ Health Perspect 2002; 110:125-8.

45. International Agency for Research on Cancer. Lists of IARC evaluations. http://Monographs. Iarc.Fr/Monoeval/Crthall.html (accessed on 26/ Mar/2006)

46. Dich J, Zahm SH, Hanberg A, Adami HO. Pesticide and cancer. Cancer Causes Control 1997; 8:420-43.

47. Silveira CTA, Bombardi S, Rego MAV, Ferreira ZM, Araújo JB. Debate sobre contaminação química, direitos das pessoas contaminadas e deveres do Poder Público. http://www2.camara.gov. $\mathrm{br} /$ comissoes/cdhm/notastaq/nt26062001.pdf (accessed on 02/Apr/2007).

48. Snedeker SM. Pesticides and breast cancer risk: a review of DDT, DDE and dieldrin. Environ Health Perspect 2001; 109 Suppl 1:35-47.

49. Romieu I, Hernandez-Avilla M, Lazcano-Ponce E, Weber JP, Dewailly E. Breast cancer, lactation history, and serum organochlorines. Am J Epidemiol 2000; 152:363-70.
50. Bohannon AD, Cooper GS, Wolff MS, Meier DE. Exposure to 1,1-dichloro-2,2-bis(p-chlorophenyl)ethylene (DDT) in relation to bone mineral density and rate of bone loss in menopausal women. Arch Environ Health 2000; 55:386-91.

51. Ross G. Risks and benefits of DDT. Lancet 2005; 366:1771-2.

52. World Health Organization. WHO gives indoor use of DDT a clean bill of health for controlling malaria. http://www.who.int/mediacenter/news/ releases/2006/pr50/en/print.html (accessed on 02/Apr/2007)

53. United Nations Children's Fund. Africa malaria report. http://rbm.who.int/amd2003 (accessed on 02/Apr/2007).

54. Attaran A, Maharaj R. Doctoring malaria, badly: the global campaign to ban DDT. BMJ 2000; 321:1403-5.

55. Rogan WJ. The DDT question. Lancet 2000; 356:1189.

56. Smith AG. How toxic is DDT? Lancet 2000; 356: 267-8.

57. Rehwagen C. WHO recommends DDT to control malaria. BMJ 2006; 333:622.

58. Mandavilli A. Health agency backs use of DDT against malaria. Nature 2006; 443:250-1.

59. Mandavilli A. DDT returns. Nat Med 2006; 12:870-1.

60. Maharaj R, Mthembu DJ, Sharp BL. Impact of DDT re-introduction on malaria transmission in KwaZulu-Natal. S Afr Med J 2005; 95:871-4.

61. Etang J, Fondjo E, Chandre F, Morlais I, Brengues C, Nwane P, et al. First report of knockdown mutations in the malaria vector Anopheles gambiae from Cameroon. Am J Trop Med Hyg 2006; 74: 795-7.

62. Cui F, Raymond M, Qiao CL. Insecticide resistance in vector mosquitoes in China. Pest Manag Sci 2006; 62:1013-22.

63. Carnevale P, Mouchet J. La lutte antivectorielle au Cameroun: passé, présent, avenir. Réflexions. Bull Soc Pathol Exot 2001; 94(2 Pt 2):202-2

64. Coleman M, Hemingway J, Sharp B. Insecticide resistance in Anopheles arabiensis and Anopheles gambiae from Mozambique. J Med Entomol 2006; 43:276-82.

65. Guyatt HL, Kinnear J, Burini M, Snow RW. A comparative cost analysis of insecticide-treated nets and indoor residual spraying in highland Kenya. Health Policy Plan 2002; 17:144-53.

66. Goodman CA, Mnzava AE, Dlamini SS, Sharp BL, Mthembu DJ, Gumede JK. Comparison of the cost and cost-effectiveness of insecticide-treated bednets and residual house-spraying in KwaZuluNatal, South Africa. Trop Med Int Health 2001; 6:280-95.

67. Bhatia MR, Fox-Rushby J, Mills A. Cost-effectiveness of malaria control interventions when malaria mortality is low: insecticide-treated nets versus in-house residual spraying in India. Soc Sci Med 2004; 59:525-39.

68. Verlé P, Lieu TT, Kongs A, Van der Stuyft P, Coosemans M. Control of malaria vectors: cost analysis in a province of northern Vietnam. Trop Med Int Health 1999; 4:139-45. 
69. Nyarango PM, Gebremeskel T, Mebrahtu G, Mufunda J, Abdulmumini U, Ogbamariam A, et al. A steep decline of malaria morbidity and mortality trends in Eritrea between 2000 and 2004: the effect of combination of control methods. Malar J 2006; 5:33.

70. Binka FN, Mensah OA, Mills A. The cost effectiveness of permethrin impregnated bednets in preventing child mortality in Kassena-Nankana district of Northern Ghana. Health Policy 1997; 41:229-39.

71. Konradsen F, van der Hoek W, Amerasinghe FP, Mutero C, Boelee E. Engineering and malaria control: learning from the past 100 years. Acta Trop 2004; 89:99-108.

72. Utzinger J, Tozan Y, Singer BH. Efficacy and costeffectiveness of environmental management for malaria control. Trop Med Int Health 2001; 6: 677-87.

73. Das PK, Amaral DD. Biological control for malaria vectors. Ind J Med Res 1997; 106:174-97.

74. Scholte E-J, Knols BGJ, Samson RA, Takkenet W. Entomopathogenic fungi for mosquito control: a review. J Insect Sci 2004; 4:1-24.

75. Lacey LA, Lacey CM. The medical importance of Riceland mosquitoes and their control using alternatives to chemical insecticides. J Am Mosq Control Assoc 1990; 11:86-9.
76. Yang M, Park MS, Lee HS. Endocrine disrupting chemicals: human exposure and health risks. J Environ Sci Health C Environ Carcinog Ecotoxicol Rev 2006; 24:183-224.

77. Cocco P. On the rumors about the silent spring: review of the scientific evidence linking occupational and environmental pesticide exposure to endocrine disruption health effects. Cad Saúde Pública 2002; 18:379-402.

78. DDT for malaria control: the issue of trade. Lancet 2007; 369:248.

79. Chen A, Rogan WL. Nonmalarial infant deaths and DDT use for malaria control. Emerg Infect Dis 2003; 9:960-4.

80. Roberts D, Curtis C, Tren R, Sharp B, Shiff C, Bate R. Malaria control and public health. Emerg Infect Dis 2004; 10:1170-1.

81. Tren R, Bate R. South Africa's war against malaria: lessons for the developing world. Policy Anal 2004; 513:1-20.

82. Roberts DR, Manguin S, Mouchet J. DDT house spraying and re-emerging malaria. Lancet 2000; 356:330-2.

83. Attaran A, Roberts DR, Curtis CF, Kilama WL. Balancing risks on the backs of the poor. Nat Med 2000; 6:729-31.

Submitted on $17 /$ Oct/2006

Final version resubmitted on 30/Apr/2007

Approved on 07/May/2007 